\title{
Yield of Solanum lycopersicum l. by applying nutrients with or without fertigation interacting with an analogue brassinosteroid
}

\author{
Reyes-Flores, Maciel; Aguirre-Medina, Juan F.*; Espinosa-Zaragoza, Saúl; Martínez-Solís, Mayra \\ ${ }^{1}$ Universidad Autónoma de Chiapas. Facultad de Ciencias Agrícolas Campus IV. Carretera Costera \\ Entronque Estación Huehuetán, Huehuetán, Chiapas, México. CP 30660.
}

*Autor de correspondencia: juaf56 aprodigy.net.mx

\begin{abstract}
Objective: To evaluate the effect of fertigation and granular fertilizer to the soil interacting with foliar application of analogue brassinosteroids in Solanum lycopersicum L.

Design/Methodology/Approach: The treatments were Fertigation (F), Fertigation plus brassinosteroids (F + BR), Granular fertilization ( $F G$ ) and Granular fertilization + brassinosteroids (FG + BRs). A completely randomized design with four replicates was used, where one plant from each treatment represented the experimental unit. Plants (45 days-old) were sprayed with $2 \mathrm{mg} \mathrm{L}^{-1}$ of Brassinosteroid CIDEF-4 and subsequent applications were made every $28 \mathrm{~d}$. Plant height and stem diameter were measured $92 \mathrm{~d}$ after transplantation, while the yield was obtained by weighing completely red fruits. An analysis of variance was performed using the GLM procedure and the Tukey means comparison test $(p \leq 0.05)$ with the SAS 9.3 program.

Results: Fertigation induced greater plant growth and reproduction of the tomato compared to the granular fertilizer with, or without foliar application of the analogue brassinosteroid. Treatments with granulated fertilizers decreased plant height by $10.36 \%$ and $10.45 \%$ compared to fertigation. Tomato yield with granulated fertilization, with or without Br. corresponded to $76.6 \%$ and $75.80 \%$ of what was achieved with Fertigation $+\mathrm{Br}$.
\end{abstract}

Study limitations/Implications: The absence of a stressful environment did not favor the application of the analogue brassinosteroid.

Findings/conclusions: Fertigation induces greater growth and yield of tomato under field conditions; and environmental temperature homogeneity did not favor morphological nor physiological expression of the analogue brassinosteroid.

Keywords: Fertigation, mineral nutrition, yield.

\section{INTRODUCTION}

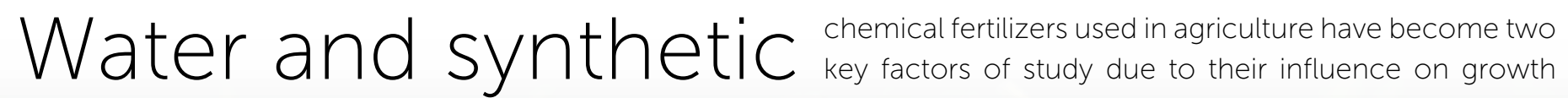
and crop productivity (Wang and Xing, 2017). They are essential inputs to face the seasonal distribution of precipitation, which generates drought in certain stages of the cultivation growth and to satisfy the nutritional needs in plants. 
Fertilization constitutes one of the essential management practices for the sustainable management of vegetables (Hernández et al., 2009). Drip irrigation has contributed to improve the efficient use of water by supplying small and frequent amounts of the liquid directly to the root zone (Karam et al., 2007; Machado et al., 2003) and with fertigation, understanding this as the application of chemical fertilizers through irrigation, which supply nutrients in quantities and frequency required by the specific phenological stage of the crop (Guzmán, 2004). The fertigation is a successful technique. However, it is essential to solve some nutritional problems in tropical regions (Hernández et al., 2009; Bravo et al., 2016). Tomato cultivation requires differentiated fertilization for each region (Silva et al., 2011) and it is important to update the levels of mineral fertilization in tomatoes to make their application more efficient, and favor production without deterioration of natural resources, facing the wide availability of cultivars for planting.

With fertigation, the availability of water and nutrients in the root zone is maintained. However, in the aerial part, the plants face contrasting environments of increased temperature and low humidity, which frequently expose the plant to thermal stress (González et al., 2006) and in this case, it has been shown that brassinosteroids $(\mathrm{Br})$, plant hormones that favor the polarization of the cell membrane (Singh and Shono, 2005), and induce resistance to biotic and abiotic stresses (Reyes et al., 2008; Nie et al., 2017), help to improve plant adaptation to local conditions. Also, BRs can influence growth when exogenous applications are made. In addition, they improve crop yield (Nie et al., 2017), as in lettuce (Lactuca sativa) (Serna et al., 2012), in fertile trilinear hybrids of Zea mays L. (Torres-Ruíz et al., 2007) or increased leaf area, as well as increased content of stevioside, rebaudioside and steviol in Stevia (Aguirre-Medina et al., 2018), particularly in high temperature conditions, hydric, saline or other abiotic stress (Núñez et al., 2001). In tomato (Solanum lycopersicum L.), BR was associated with the production of ethylene, with increasing the content of lycopene and carbohydrates (Vardhini and Rao, 2002). In transgenic tomatoes, the number of fruits and yield was increased, but decreased the individual weight of the fruit; likewise, it resulted in early flowering and a significant reduction in maturation time (Nie et al., 2017). Thus, fertigation and granular fertilization were evaluated in tomato cultivation, with/without the foliar application of one analogue brassinosteroid in plants of Solanum lycopersicum L.

\section{MATERIALS AND METHODS}

The experiment was established during the autumnwinter cycle of 2019 in the Experimental Field of the Facultad de Ciencias Agrícolas, Campus IV, located at the junction of the coastal road and Huehuetán Station, municipality of Huehuetán. The type of climate $\mathrm{Aw}_{2}$ i g, which corresponds to tropical warm-humid with rains in summer. The average annual rainfall of 2,415 mm between the months of May to November. During the research, there was no precipitation, and the averages of maximum, minimum and mean temperatures were 35.0, 20.6 and $27.8^{\circ} \mathrm{C}$ from November to March.

The soil is of a sandy-loam texture $166.48 \%$ sand, $23.72 \%$ silt, $9.80 \%$ clay), $1.7 \%$ organic matter, electrical conductivity of $0.03 \mathrm{dS} \mathrm{m}^{-1}, 6.25 \mathrm{meq} 100 \mathrm{~g}^{-1}$ capacity of cation exchange, $\mathrm{pH} 5.7,0.07 \%$ of N, P $15.45 \mathrm{mg} \mathrm{kg}^{-1}$, $\mathrm{K} 238.0 \mathrm{mg} \mathrm{kg}^{-1}, \mathrm{Ca} 704 \mathrm{mg} \mathrm{kg}^{-1}, \mathrm{Mg} 157.5 \mathrm{mg} \mathrm{kg}^{-1}$ and Na $168.0 \mathrm{mg} \mathrm{kg}^{-1}$. The cultivar 'Pony Express' was used for S. lycopersicum (Harris Moran ${ }^{\circledR}$ ), of a determined early Saladette type, with uniform fruits in size, shape and deep red color.

The seeds were germinated in polystyrene trays of 200 cavities and $25 \mathrm{~mL}$ of volume in each cavity in Growing Mix ${ }^{\circledR}$ peat-moss as substrate. The transplant was carried out $35 \mathrm{~d}$ after sowing in the open field by means of fertigation, which was applied with a strip $20 \mathrm{~cm}$ apart between drippers, in furrows $0.8 \mathrm{~m}$ wide and $0.50 \mathrm{~m}$ apart between plants. The plants were driven to a single stem, removing the lateral shoots. Only three bunches per plant were harvested, when the fruits were ripe.

In fertigation, the Steiner nutrient solution was used (Steiner, 1984) and its base composition was in molc $\mathrm{m}^{-3}: 12 \mathrm{NO}_{3}^{-}, 1 \mathrm{H}_{2} \mathrm{PO}_{4}^{-}, 3.5 \mathrm{SO}_{4}^{2-}, 7 \mathrm{~K}^{+}, 2 \mathrm{Mg}^{2+}$ y 4.5 $\mathrm{Ca}^{2+}$ with $5.8 \mathrm{pH}$ and electrical conductivity of $2 \mathrm{dS} \mathrm{m}^{-1}$. Granulated fertilization was performed by applying deep fertilization with $20 \mathrm{~g}$ of diammonium phosphate (DAP) and subsequently, soil applications were made every $8 d$ with $15 \mathrm{~g}$ of urea and $4 \mathrm{~g}$ of potassium chloride.

The soluble Brassinosteroid CIDEF-4TM (Natura del Desierto, SA. de CV.) with $80 \%$ steroidal content and 10\% active ingredient, $2 \mathrm{mg} \mathrm{L}^{-1}$ were sprayed every $28 \mathrm{~d}$ to the point of dripping per plant.

Four treatments were established: Fertigation (F), Fertigation plus brassinosteroid ( $F+B R$ ), Granular 
fertilization (GF), and Granular fertilization + brassinosteroid (GF + BRs). The experiment was conducted as a completely randomized design with four replicates; one plant from each treatment formed the experimental unit.

Variables were, plant height $(\mathrm{cm})$, recorded with a tape measure from the root crown to the apical bud; and stem diameter, measured at a height of $5 \mathrm{~cm}$ from the root crown up, with a digital Vernier (Sure Bilt. USA) at $92 \mathrm{~d}$ after transplant. Tomato yield was obtained by weighing the fruits per bunch on a digital scale (ADIR, model 1676). An analysis of variance was performed using the GLM procedure and the Tukey mean comparison test ( $\mathrm{P} \leq 0.05)$, using SAS 9.3 program (SAS Institute, 2010).

\section{RESULTS AND DISCUSSION}

The height and thickness of the stem increased in the treatments with fertigation and were statistically different from the rest $(p \leq 0.05)$ (Table 1$)$. Treatments with granulated fertilizers decreased $10.36 \%$ and $10.45 \%$ when compared to the best treatment. Analogue brassinosteroid did not show a positive effect in either of the fertilization forms. This is attributed to temperature uniformity during the study period. Maximum temperature values were 34$35{ }^{\circ} \mathrm{C}$ and the minimum average temperature ranged from 19.9 to $20.3^{\circ} \mathrm{C}$.

In another similar sowing, with the application of the brassinosteroid BIOBRAS-6, Mazorra and Núñez (2003) did not register differences in the length of the stem when it was applied to tomato seeds var. Amalia, at two concentrations of 0.01 and $0.05 \mathrm{mg} \mathrm{L}^{-1}$. In contrast, at a $10^{-8} \mathrm{M}$ concentration of Brasinosteroid applied to the foliage, Hasan et al., (2014) referred increases of $57.56 \%$

\begin{tabular}{|c|c|c|c|}
\hline Treatment & Yield (kg plant ${ }^{-1}$ ) & Plant height (cm) & Stem diameter $(\mathrm{cm})$ \\
\hline $\mathrm{F}+\mathrm{Br}$ & $1.24 a^{z}$ & $114.35 a$ & $0.90 \mathrm{a}$ \\
\hline $\mathrm{F}$ & $1.25 \mathrm{a}$ & 115.27 a & $0.90 \mathrm{a}$ \\
\hline $\mathrm{GF}+\mathrm{Br}$ & $0.95 \mathrm{~b}$ & $102.50 \mathrm{~b}$ & $0.82 \mathrm{~b}$ \\
\hline GF & $0.94 b$ & $102.40 \mathrm{~b}$ & $0.82 b$ \\
\hline YHMSD & 0.49 & 3.14 & 0.06 \\
\hline${ }^{X} \mathrm{CV}(\%)$ & 2.12 & 1.38 & 3.70 \\
\hline \multicolumn{4}{|c|}{$\begin{array}{l}\text { ZDifferent letter values, within columns, are statistically different (Tukey, } \mathrm{p} \leq 0.05 \text { ); } \\
\mathrm{YDMSH}=\text { Honest minimum significant difference; } \mathrm{XCV}=\text { Coefficient of variation; } \mathrm{F} \\
+\mathrm{Br}=\text { fertigation plus brassinosteroid; } \mathrm{F}=\text { fertigation; } \mathrm{GF}+\mathrm{Br}=\text { Granular fertilization } \\
\text { plus brassinosteroid; } \mathrm{GF}=\text { Granular fertilization. }{ }^{\star} \text { (das) days after sowing. }\end{array}$} \\
\hline
\end{tabular}

in the length of tomato plant. Vardhini and Rao (2001) cited the same result of increasing in plant size $130.57 \%$ and $33.95 \%$, respectively) when 28-homobrasinolide $(\mathrm{HBL})$ and 24-epibrasinolide (EPL) were applied to the foliage at $3.0 \mu \mathrm{M}$ concentration (Vardhini and Rao, 2001).

\section{Fruit yield}

Differences in yield were mainly due to the contribution of nutrients and the method of application. In fertigation, more nutrients were provided for the better development of plants compared to granular fertilization. There were highly significant differences $(p \leq 0.05)$ in fruit yield attributed to the treatments. The yield with GF + BR and GF correspond to $76.6 \%$ and $75.80 \%$ of what was achieved with $\mathrm{F}+\mathrm{BR}$ (Table 1). The difference in yield between the two forms of fertilization is attributed to the ample supply of nutrients that fertigation provides in comparison to granular NPK fertilization; and according to Sainju et al. (2003) nutrient concentration in the tomato cultivation influences the yield.

Authors such as Dabire et al. (2016) stated, by comparing organic fertilization with mineral fertilization on $S$. lycopersicum var. Mongal F1, that there was no significant effect on the chemical compounds contained in the fruit, with the mineral application. The absence of response in tomato yield to the application of the Brassinosteroid CIDEF-4 is related to the absence of an environmental temperature stress, which was otherwise expected, due to the recurrent increase in temperature that has characterized the region in recent years, which induces flower drop. However, other reported results are 10.32\% increment in yield when the signaling gene BRI1 is used (Nie et al., 2017). It was also indicated that the use of HBL (28-homobrassinolide) and EBL (24-epibrassinolide) increased yield in tomato varieties $\mathrm{K}-25$ (49.12\%; HBL and 52.63\%; EBL) and Sarvodaya (34.38\%; HBL and 41.67\%; EBL) (Hassan et al., 2014). Similarly, the foliar application of brassinolide, 28-homobrasinolide and 24-epibrasinolide in $3.0 \mu \mathrm{M}$ concentration increased fruit yield by $53.98 \%, 70.15 \%$ and $67.37 \%$, respectively (Vardhini and Rao, 2001).

In relation to homobrassinolide, and according to Hernández-Silva and GarcíaMartínez (2016), they do not have much effect on plant growth when growing conditions are optimal. Although BRs 
are considered a kind of hormone with great potential to increase the yield of crops (Vriet et al., 2012), foliar application of BRs aims to improve plant response to stress, since BR promote resistance in plants against low temperature and low light, increasing fresh and dry weight, and maintaining photosynthetic activity (Shu et al., 2016); generating basic thermic tolerance in pollen germination (Sing and Shono, 2005) and accumulating ethylene under salt stress (Zhu et al., 2016).

Authors such as Corbera and Nunez (2004), by evaluating analogue brassinosteroid $\mathrm{Bb}-6$ on Glycine max, inoculated with Bradyrhizobium japonicum and arbuscular mycorrhizal fungus, mentioned that the variables, plant and weight of 100 seeds were little influenced by the application of mycorrhiza or the coinoculation with Bradyrhizobium strain; likewise, with the application of the analogue brassinosteroid.

Regarding the fertilization method, fertigation increased tomato yield in $21.7 \%, 10.5 \%$ and $25.3 \%$ and it was associated with a greater number and size of fruits per plant, compared to the direct application of solid fertilizers to the soil (Badr et al., 2010; Hebbar et al., 2004; Shedeed et al., 2009). In okra (Abelmoschus esculentus), under fertigation, there was an increase of $25.21 \%$ and $16.5 \%$ in two production cycles, saving $40 \%$ of fertilizers compared to the traditional method (Patel and Rajput, 2004).

\section{Fruit weight}

The fruit weight showed highly significant differences $(p \leq 0.05)$ in the three bunches evaluated. In fertigation treatments, a higher fruit weight was observed, as compared to treatments with granulated fertilizer (Table 2).

\section{REFERENCES}

Aguirre-Medina, J. F., Mina-Briones, F. O., Cadena-Iñiguez, J. y SotoHernández, R. M. 2018. Efectividad de biofertilizantes y brasinoesteroide en Stevia rebaudiana Bert. Agrociencia 52: 609-621.

Badr, M. A., Hussein, S. A., El-Tohamy, W. A., and Gruda, N. 2010. Nutrient uptake and yield of tomato under various methods of fertilizer application and levels of fertigation in arid lands. Gesunde Pflanzen 62: 11-19. doi: 10.1007/s10343-010-0219-5

Bravo, I., Yucra, R., Mazuela, P. 2016. Efecto de la fertirrigación en un cultivo de tomate sobre la sostenibilidad agrícola de un valle costero del desierto de Atacama, Chile. IDESIA (Chile), 34(6): 75-78.

Corbera, J. Núñez, M. 2004. Evaluación agronómica del análogo de brasinoesteroides bb-6 en soya, inoculada con bradyrhizobium japonicum y HMA, cultivada en invierno sobre un suelo ferralsol. Cultivos Tropicales, 25(3): 9-13

Dabire, C., Sereme, A., Parkouda, C., Somda, M.K., Traore, A.S. 2016 Influence of organic and mineral fertilizers on chemical and biochemical compounds content in tomato (Solanum lycopersicum) var. mongal f1. Journal of Experimental Biology and Agricultural Sciences, 4(6): 631-636. doi: http://dx.doi.org/ 10.18006/2016.4(Issue6).631.636

Hasan, S. A., Irfan, M. and Hayat, S. 2014. Response of tomato cultivars on yield and quality attributes applied with two different modes of BR analogues: A comparative study. In International Conference on Advances in Agricultural, Biological \& Environmental Sciences (AABES-2014): 15-16

Karam, F., Lahoud, R., Masaad, R., Kabalan, R., Breidi, J., Chalita, C., and Rouphael, Y. 2007. Evapotranspiration, seed yield and water use efficiency of drip irrigated sunflower under full and deficit irrigation conditions. Agricultural water management 90: 213223. doi:10.1016/j.agwat.2007.03.009

Kumar, M., Meena, M. L., Kumar, S., Maji, S., \& Kumar, D. (2013). Effect of nitrogen, phosphorus and potassium fertilizers on the growth, yield, and quality of tomato var. Azad T-6. The Asian Journal of Horticulture, 8, 616-619

Li, X. J., Chen, X. J., Guo, X., Yin, L. L., Ahammed, G. J., Xu, C. J., Shen, K. S., Liu, C. C., Xia, X. J, Shi, K., Zhou, J., Zhou, Y. H. and Yu, J. Q. 2016. Dwarf over expression induces alteration in phytohormone homeostasis, development, architecture and carotenoid accumulation in tomato. Plant Biotechnology
It is evident that the form of fertilization induces greater growth of the tomato and affects yield directly. Kumar et al. (2013) and Zhang et al. (2010) cited differences with the application of different levels of fertilizer in the Azad T-6 tomato variety.

\section{CONCLUSIONS}

Fertigation induces greater growth and yield in tomato at field condition. The homogeneity of ambient temperatures did not favor the expression of the analogue brassinosteroid.

\begin{tabular}{l|c|c|c}
\multirow{2}{*}{$\begin{array}{l}\text { Table 2. Fruit weight per cluster of Pony Express tomato plants. } \\
\text { Treatment }\end{array}$} & \multicolumn{3}{|c}{ Fruit weight (g) } \\
\cline { 2 - 4 } & Cluster 1 & Cluster 2 & Cluster 3 \\
\hline $\mathrm{F}+\mathrm{Br}$ & $77.50 \mathrm{a}^{\mathrm{Z}}$ & $89.65 \mathrm{a}$ & $82.55 \mathrm{a}$ \\
\hline $\mathrm{F}$ & $82.85 \mathrm{a}$ & $83.35 \mathrm{~b}$ & $84.60 \mathrm{a}$ \\
\hline $\mathrm{GF}+\mathrm{Br}$ & $64.15 \mathrm{~b}$ & $63.70 \mathrm{c}$ & $62.55 \mathrm{~b}$ \\
\hline $\mathrm{GF}$ & $64.00 \mathrm{~b}$ & $62.70 \mathrm{c}$ & $61.60 \mathrm{~b}$ \\
\hline${ }^{\mathrm{Y}} \mathrm{DMSH}$ & 5.35 & 4.47 & 5.12 \\
\hline${ }^{\mathrm{X}} \mathrm{CV}(\%)$ & 8.93 & 7.18 & 8.48 \\
\hline
\end{tabular}

${ }^{z}$ Different letter values, within columns, are statistically different (Tukey, $p \leq 0.05$ ): YDMSH $=$ Honest minimum significant difference; $X C V=$ Coefficient of variation; $\mathrm{F}+\mathrm{Br}=$ fertigation plus brassinosteroid; $\mathrm{F}=$ fertigation; $\mathrm{GF}+\mathrm{Br}=$ Granular fertilization plus brassinosteroid; GF = Granular fertilization . 
Journal 14: 1021-1033. Article ID. 26383874 doi: 10.1111/ pbi.12474

González, F. M., Casanova, A., Hernández, A., Méndez, M., González, R. Delgado, A. Bravo, E. 2006. Efecto de la aplicación de Biobras-16 en la producción de plántulas injertadas de tomate (Lycopersicon esculentum Mill). Temas de Ciencia y Tecnología, 10 (30): 53 - 56.

Guzmán, M. 2004. Población, agua, suelo y fertilizantes: El ferti-riego. p. 5-10 In Guzmán, P. J. M., y López G. J. (eds.). Programa Ciencia y tecnología para el desarrollo (CYTED). Madrid, España.

Hernández, M.I., Chailloux, M., Moreno, V., Mojena, M., Salgado, J. M. 2009 Relaciones nitrógeno-potasio en fertirriego para el cultivo protegido del Tomate (Solanum lycopersicum L.) y su efecto en la acumulación de biomasa y extracción de nutrientes. Cultivos Tropicales, 30(4): 71-78

Machado, R. M., Do Rosário, M., Oliveira, G., and Portas, C. A. 2003 Tomato root distribution, yield and fruit quality under subsurface drip irrigation. Plant and Soil 255: 333-341. doi:10.1023/A:1026191326168

Mazorra, L. M. y Núñez, M. 2003. Influencia de análogos de brasinoesteroides en la respuesta de plantas de tomate a diferentes estrés ambientales. Cultivos Tropicales 24: 35-40.

Nie, S., Huang, S., Wang, S., Cheng, D., Liu, J., Lv, S., Li, Q. and Wang, X. 2017. Enhancing brassinosteroid signaling via overexpression of tomato (Solanum lycopersicum) SIBRI1 improves major agronomic traits. Frontiers in Plant Science 8: 1386. doi 10.3389/fpls.2017.01386

Núñez Vázquez, M. Mazorra, L.M. (2001) Los brasinoesteroides y la respuesta de las plantas al estrés. Cultivos tropicales (3): 19-26.

Patel, N., and Rajput, T. B. S. 2004. Fertigation-a technique for efficient use of granular fertilizer through drip irrigation. El Journal 85 50-54.

Reyes, Y., Mazorra, L. M., Núñez, M. 2008 Aspectos fisiológicos y bioquímicos de la tolerancia del arroz al estrés salino y su relación con los brasinoesteroides. Cultivos Tropicales 29: 6775 .

Sainju, U. M., Dris, R. y Singh, B. 2003. Mineral nutrition of tomato. Food, Agriculture \& Environment 1:176-183.

Serna, M., Hernández, F., Coll, F. and Amorós, A. 2012. Brassinosteroid analogues effect on yield and quality parameters of field-grown lettuce (Lactuca sativa L.). Scientia Horticulturae 143: 29-37 doi: 10.1016/j.scienta.2012.05.019

Shedeed, S. I., Zaghloul, S. M., and Yassen, A. A. 2009. Effect of method and rate of fertilizer application under drip irrigation on yield and nutrient uptake by tomato. Ozean Journal of Applied Sciences 2: 139-147.

Shu, S., Tang, Y., Yuan, Y., Sun, J., Zhong, M., and Guo, S. 2016. The role of 24-epibrassinolide in the regulation of photosynthetic characteristics and nitrogen metabolism of tomato seedlings under a combined low temperature and weak light stress. Plant physiology and biochemistry 107: 344-353. Article ID: 27362298 doi: 10.1016/j.plaphy.2016.06.021

Silva, E. C., Maciel, G. M., Alvarenga, P. P. M., \& Paula, A. C. C. F. F. (2011). Teores de $\beta$-caroteno e licopeno em função das doses de fósforo e potássio em frutos de diferentes genótipos de tomateiro industrial. Bioscience Journal, 27, 247-252

Singh, I., and Shono, M. 2005. Physiological and molecular effects of 24-epibrassinolide, a brassinosteroid on thermotolerance of tomato. Plant Growth Regulation 47: 111. doi: 10.1007/s10725005-3252-0

Smith, S. M., Li, C. y Li, J. 2017. Hormone function in plants. p. 1-38. In Li J., Li C. y Smith S. M. (eds.). Hormone metabolism and signaling in plants. Academic Press

Steiner, A. A. (1984). The universal nutrient solution. Proceeding of the Sixth International Congress on Soilless Culture. International Society for Soilless Culture. Lunteren, Netherlands. 633-649.

Torres-Ruiz, B. L., Espinosa-Calderón, A., Mendoza-Rodríguez, M., Irizar-Garza, M. B. y Castellano-Ruiz, J. S. 2007. Efecto de brasinoesteroides en híbridos de maíz androestériles y fértiles. Agronomía Mesoamericana 18: 155-162. doi: 10.15517/ am.v18i2.5045

Vardhini, B. V., y Rao, S. S. R. 2001. Effect of brassinosteroids on growth and yield of tomato (Lycopersicon esculentum Mill.) under field conditions. Indian Journal of Plant Physiology 6: 326-328.

Vardhini, B.V., and Rao, S.S.R. 2002. Acceleration of ripening of tomato pericarp discs by brassinosteroids. Phytochemistry 61: 843847. Article ID: 12453577 doi: 10.1016/s0031-9422(02)00223-6

Vriet, C., Russinova, E. y Reuzeau, C. 2012. Boosting crop yields with plant steroids. The Plant Cell 24: 842-857. doi: 10.1105/ tpc.111.094912

Wang, H., Wei Z., Li J. y Wang X. 2017. Brassinosteroids. p. 291-326. In Li J., Li C. y Smith S. M. (eds.). Hormone metabolism and signaling in plants. Academic Press.

Wang, X., and Xing, Y. 2017. Evaluation of the effects of irrigation and fertilization on tomato fruit yield and quality: a principal component analysis. Scientific reports 7: 1-13. doi:10.1038/ s41598-017-00373-8

Zhang, T. Q., Tan, C. S., Liu, K., Drury, C. F., Papadopoulos, A. P., \& Warner, J. (2010). Yield and Economic Assessments of Fertilizer Nitrogen and Phosphorus for Processing Tomato with Drip Fertigation. Agronomy Journal, 102, 774. https://doi. org/10.2134/agronj2009.0346

Zhu, T., Deng, X., Zhou, X., Zhu, L., Zou, L., Li, P., Zhang, D., and Lin, H. 2016. Ethylene and hydrogen peroxide are involved in brassinosteroid-induced salt tolerance in tomato. Scientific Reports 6: 35392. doi: 10.1038/srep35392 